\title{
Causes for professionalization in national sport federations in Switzerland: a multiple-case study
}

\author{
Kaisa Ruoranen 1, ", Josephine Clausen², Siegfried Nagel', Grazia Lang' ', Christoffer Klenk', \\ David Giauque ${ }^{3}$, Emmanuel Bayle ${ }^{2} \&$ Torsten Schlesinger ${ }^{4}$ \\ 1 Institute of Sport Science, University of Bern, Bern, Switzerland \\ 2 Institute of Sport Sciences, University of Lausanne, Lausanne, Switzerland \\ 3 Institute of Political and International Studies, University of Lausanne, Lausanne, Switzerland \\ 4 Institute of Human Movement Science, Chemnitz University of Technology, Chemnitz, Germany \\ * Corresponding author: Institute of Sport Science, University of Bern, Bremgartenstrasse 145, CH-3012 Bern, Switzerland, \\ Tel: +4131 6315666, Fax: +41316314631 \\ Email: kaisa.ruoranen@ispw.unibe.ch
}

ORIGINAL ARTICLE

Article History:

Submitted 20 ${ }^{\text {th }}$ October 2017

Accepted $8^{\text {th }}$ January 2018

Published $8^{\text {th }}$ February 2018

Handling Editor:

Otmar Weiß,

University of Vienna, Austria

Editor-in-Chief:

Martin Kopp

University of Innsbruck, Austria

Reviewers:

Reviewer 1: Michael Barth, Friedrich-

Schiller-University Jena, Germany

Reviewer 2: Martin Schnitzer,

University of Innsbruck, Austria

\section{ABSTRACT}

Aim and design: This study explores causes for professionalization in Swiss national sport federations (NSFs). We conducted a multiple-case study employing a qualitative approach with interviews and documents from seven NSFs. A three-level framework guided the analysis in distinguishing NSFs endogenous causes, and causes in their external and internal environment.

Results: Causes for professionalization were widely similar in the NSFs. Conflicts on the board, unclear decision-making competences and initiatives of key persons have prominently triggered professionalization, particularly for differentiation of strategic boards and executive headquarters, specialization and paid staff. The Swiss government, Swiss Olympic Association and sponsors (external environment) have brought about considerable adaptations in NSFs' strategies, accountability issues and commercialization, whereas expectations of NSFs' member organizations (internal environment) have had little impact on their professionalization in general. Rather, the NSFs view them as necessities they themselves do not perceive. Our analysis revealed additional NSF-specific factors (e.g., popularity, financial resources, attitude of individuals towards professionalization) that have an impact on pace and continuity of the process once it has been initiated.

Conclusion: Our analysis is a first step towards understanding the professionalization process in Swiss NSFs. Referring to the similar causes for professionalization, uncertainty and competing for resources may have led some NSFs to mimic those NSFs they deem successful, leading to similar conditions that call for professionalization (e.g., with respect to workload and internal expectations). Respective networks between motivated people in the NSFs and stakeholders could support a deliberate professionalization. NSFs endogenous and NSF external causes for professionalization seem to be reciprocal. This should be considered more specifically in the analysis of professionalization in NSFs. Single-case studies would be useful to understand the mechanisms and eventual phases more clearly, to identify eventual barriers and avoid unintended consequences to, finally, support NSFs' professionalization in an efficient manner.

Keywords:

Professionalization - organizational change - sport federation - sport organization multiple-case study

Citation:

Ruoranen, K., Clausen, J., Nagel, S., Lang, G., Klenk, C., Giauque, D., Bayle, E. \& Schlesinger, T. (2018): Causes for professionalization in national sport federations in Switzerland: a multiple-case study. Current Issues in Sport Science, 3:003. doi: 10.15203/CISS_2018.003 


\section{Introduction}

To align with current societal norms, such as modernity, rationality and accountability, national sport federations (NSF) need to reflect on their structures and processes and make appropriate adjustments. Doing so is vital for gaining legitimation in the organizational environment and society and garnering the financial resources essential for them to be able to meet their goals (e.g., Child \& Rodrigues, 2011; Doherty, Misener, \& Cuskelly, 2014). Seemingly, common responses to the new challenges have been, for example, establishment of new management structures, governance, formalization of daily practice, and employment of people with specific qualifications (Dowling, Edwards, \& Washington, 2014). Furthermore, strengthening their position against public and private institutions, and a range of stakeholders (state, sponsors, member clubs, media, etc.), sport federations need to respond to multiple liability issues (Bayle \& Madella, 2002; Evetts, 2011; Kikulis, 2000; Slack \& Hinings, 1992). Organizational adaptation in sport federations has been described as a transformation 'from a volunteer driven to an increasingly business-like phenomenon' (Chantelat, 2001; Dowling et al., 2014). The development can be summarized as a form of professionalization that is undertaken to manage present challenges (e.g., Dowling et al., 2014; Skinner, Steward, \& Edwards, 1999). The objective of this study is to explore causes for professionalization in Swiss NSFs. We aim to uncover NSFs endogenous causes, and expectations from their external and internal environment that cause professionalization.

To consider a comprehensive transformation, we refer to professionalization in a broad sense addressing structures and processes, strategies and activities, as well as persons and positions of the NSF (Ruoranen, Klenk, Schlesinger, Bayle, Clausen, Giauque, et al., 2016).

Studying professionalization in sport organizations is not new (Dowling et al., 2014; Nagel, Schlesinger, Bayle, \& Giauque, 2015). However, studies on causes of professionalization in sport organizations tend to consider only a few organizational factors that can promote or hinder the process of professionalization (e.g., growing tasks, financial resources, organizational values). Current research also lacks differentiation between internal and external causes that may, however, have relevance for detecting interrelationships between NSF internal pressures and expectations from their environment for professionalization. We endeavor to fill these gaps through a multiple-case study in the Swiss context. The cases, which include not only popular but also less popular sports that have been ignored so far in previous, prominently Anglo-Saxon studies (Dart, 2014), will be investigated by applying a multi-level framework for analyzing causes for professionalization (Nagel et al., 2015). In doing so, we contribute to the knowledge of relations of professionalization in the headquarters to their member organizations that - aside from Ferkins and Shilbury's study (2010) on national-regional governing relationship - has received little attention (Dowling et al., 2014). In addition to knowledge on development of NSFs, we aim to contribute to analytical and theoretical concepts of professionalization. Understanding how change evolves and knowing more about mechanisms behind professionalization processes in different NSFs from the same field can aid them in avoiding ineffective service and strategy development. This is particularly important, because NSFs are largely financed by membership fees and public grants.

In the next section, we present the conceptual background of the paper and related previous research. Thereafter, the Swiss sport system - the environment of the analyzed NSF is introduced, followed by our method. The results are divided into three subsections along the analytical framework, and, finally, discussed.

\section{Conceptual background and previous research}

Nagel et al. (2015) have summarized the current sport management and sport sociological literature and positioned forms, causes and consequences of professionalization in sport federations into a multi-level framework. The review is based on three dimensions of professionalization according to Bayle and Robinson (2007) and Legay (2001): professionalization of 1) activities (e.g., quality management), 2) individuals (e.g., qualification, paid employment), and 3) structure and processes (e.g., board structure, formalization). The review embraces various theoretical backgrounds (e.g., contingency, agency and institutional theory) and presents causes for professionalization on three levels: endogenous causes (e.g., increased workload and key persons), and causes in federations' external and internal environment (e.g., pressure from sponsors and requirements of umbrella organizations, or expectations from member organizations).

The review uncovers a mainly constructionist perspective on professionalization. On the one hand, professionalization in sport federations has been caused by pressure from their external environment. On the other hand, NSFs respond to the pressure differently. In particular, the interests of NSFs and stakeholders may differ, because NSFs are committed to their members' interests. Therefore, we should also consider NSFs endogenous conditions as affecting changes in sport organizations (e.g., Horch \& Schütte, 2009). Kikulis and colleagues (Kikulis, Slack, \& Hinings, 1995) explained variation in organizations' responses to institutional pressures with the active role of key actors in the design of organizations. Interests of organizational members and their decisions characterized the stepwise changes, for example towards (de-)centralization. Amis, Slack and Hinings (2002) found that Canadian national sport organizations, whose members held values congruent with the prescribed changes, were able to make large-scale organizational change successfully. Conversely, organizations whose members opposed the changes entered into a period of largely superficial conformity. Also, O'Brien and Slack (2003) explain differences in the transition from amateur to professional status in UK rugby clubs by values and beliefs of 
powerful new actors who brought professionally orientated institutional logic with them. They pointed out that, while elite support is necessary for radical change, it is not sufficient.

While these approaches build on interests and decisions of key actors, other scholars apply the contingency theory and assess other (internal) situational characteristics as effecting changes in (sport) organizations. These can be, for example, financial resources, size, culture, and leadership relations (Horch \& Schütte, 2009). Slack and Hinings (1992), for example, found a considerable hindering influence of organizational culture (e.g., shared operating norms, ideology, myths) that was challenged by professionalization. Resistance of volunteers, for example, often stems from fear that changes erode the traditional values of the organization (Horch \& Schütte, 2009; Slack \& Hinings, 1992; Welty Peachey, Zhou, Damon, \& Burton, 2015). Scarce financial resources are another situational characteristic hindering professionalization, whereas international competition and media coverage may promote it (Nagel et al., 2015).

Expectations from stakeholders, such as the state or umbrella organizations, (e.g., National Olympic Associations), have often been considered important for understanding professionalization from neo-institutionalist perspectives (Washington \& Patterson, 2011). Funders or collective actors such as political institutions, but also evolutions in civic and economic conditions can cause changes in processes and structures, and affect a transition of nonprofit organizations (NPOs) in general towards businesslike organizations (Maier, Meyer, \& Steinbereithner, 2016; Seippel, 2002; Vos, Breesch, Késenne, Van Hoecke, Vanreusel, \& Scheerder, 2011). Pressure from the external environment can be coercive, normative or mimetic, with the tendency to result in isomorphic organizations within their field (DiMaggio \& Powell, 1983; Slack \& Hinings, 1994).

Since sport policy, the logic and proportion of subsidies of the total income of sport organizations differ between countries, the impact of the external environment on professionalization of NSFs probably depends on the specific national sport system, and varying coercive pressures of governments. Several studies (e.g., Amis et al., 2002; Edwards, Mason, \& Washington, 2009; Slack \& Hinings, 1994) have found clear coercive pressure by the government in Canada, whereas in Norway and Belgium the pressure through state funding has been rather low (Seippel, 2002; Vos et al., 2011). The influence of the state and other stakeholders on NSFs through conditioned subsidies reveals that NSFs depend on external resources to be able to perform their activities (Pfeffer \& Salancik, 2003). Through resource dependence, the state can control sport organizations' actions and have the potential to instrumentalize them (as intentionally operating agents) for sport policy (Vos et al., 2011).

Against this background, it may be interesting to investigate circumstances causing professionalization from a multi-level perspective in a specific state context. We believe that it is important to consider institutional influences, individual key actors, as well as internal unintended stimuli equally. For that purpose, the multi-level framework of Nagel et al. (2015) appears an eligible entry. For a better understanding of the mechanisms behind professionalization, we intend to contribute to refining that framework by means of inductively collected empirical data from NSFs. Hence, we explore what role the state, member organizations and other stakeholders play in the professionalization of NSFs in Switzerland, whose sport system is relatively open and where NSFs are permitted autonomy. Also, we examine whether there are other, more instrumental influences or interests dominating professionalization of Swiss NSFs. Consequently, this study explores 1) NSFs endogenous causes, 2) expectations from their external environment, and 3) expectations from their internal environment that cause professionalization in Swiss NSFs.

\section{Swiss sport system}

In Switzerland, sport policy is based on principles of subsidiarity and autonomy. The implementation follows the Swiss federal policy system (Bayle, 2017; Chappelet, 2010; Kriesi \& Trechsel, 2008), constituted on a federal, cantonal and municipal level. The Federal Office of Sport (FOSPO), together with the NSFs, are responsible for policy development. However, the 86 NSFs and their umbrella organization, Swiss Olympic (SO), are responsible for implementation of the policy. They organize both grassroots and top-level sports autonomously, which opens the system for individual and collective initiatives. While both are widely independent from the Confederation, the only supervisor who can have direct impact on the NSFs is SO (Bayle, 2017). To support and strengthen its member NSFs, SO has established a federation promotion concept whose central element is an agreement about the NSF's goals. The financial support to reach the agreed performance is bound to five "promotion categories," to which each NSF is assigned. For the categorization into 1-5 (1 qualifying for the highest grant), SO uses several criteria regarding both characteristics of the sport (e.g., individual/team) and organization of the NSF (e.g., manager). Nevertheless, for the most part, the NSFs are autonomous in implementing the organization development strategy of SO.

\section{Method}

To analyze factors contributing to professionalization in Swiss NSFs, a multiple-case study was conducted, applying a qualitative content analysis according to Gläser and Laudel $(2010,2013)$. Semi-structured interviews and public documents of seven Swiss NSFs were analyzed inductively. The study contributes to a bigger study project on professionalization of national and international sport federations.

\section{Selection of cases}

A purposive sample of NSF was achieved by considering number of members, sport (individual/team, winter/summer, 
Olympic/non-Olympic), as well as the NSF's scope (single/ multiple disciplines) (Table 1). To consider also NSFs whose scope differ from common NSFs, the umbrella federation of sports for people with disabilities PluSport was included. Data were collected by means of interviews with key persons and analysis of available, mainly public documents. The availability and points of reference in the documents were crucial for the approximate period of analysis, mainly addressed also in the interviews. Overall, roughly the last ten years were covered.

\section{Data collection}

Documents. Documents were analyzed ahead of interviews to collect information and get familiar with crucial reference points in the NSF's development as well as its previous plans. Some documents, especially annual reports and protocols, look back and can thus be used to create a chronology due to their regularity. Causes for professionalization were assigned to three levels in a data matrix: NSFs endogenous, NSFs' external

Table 1: Selection of cases

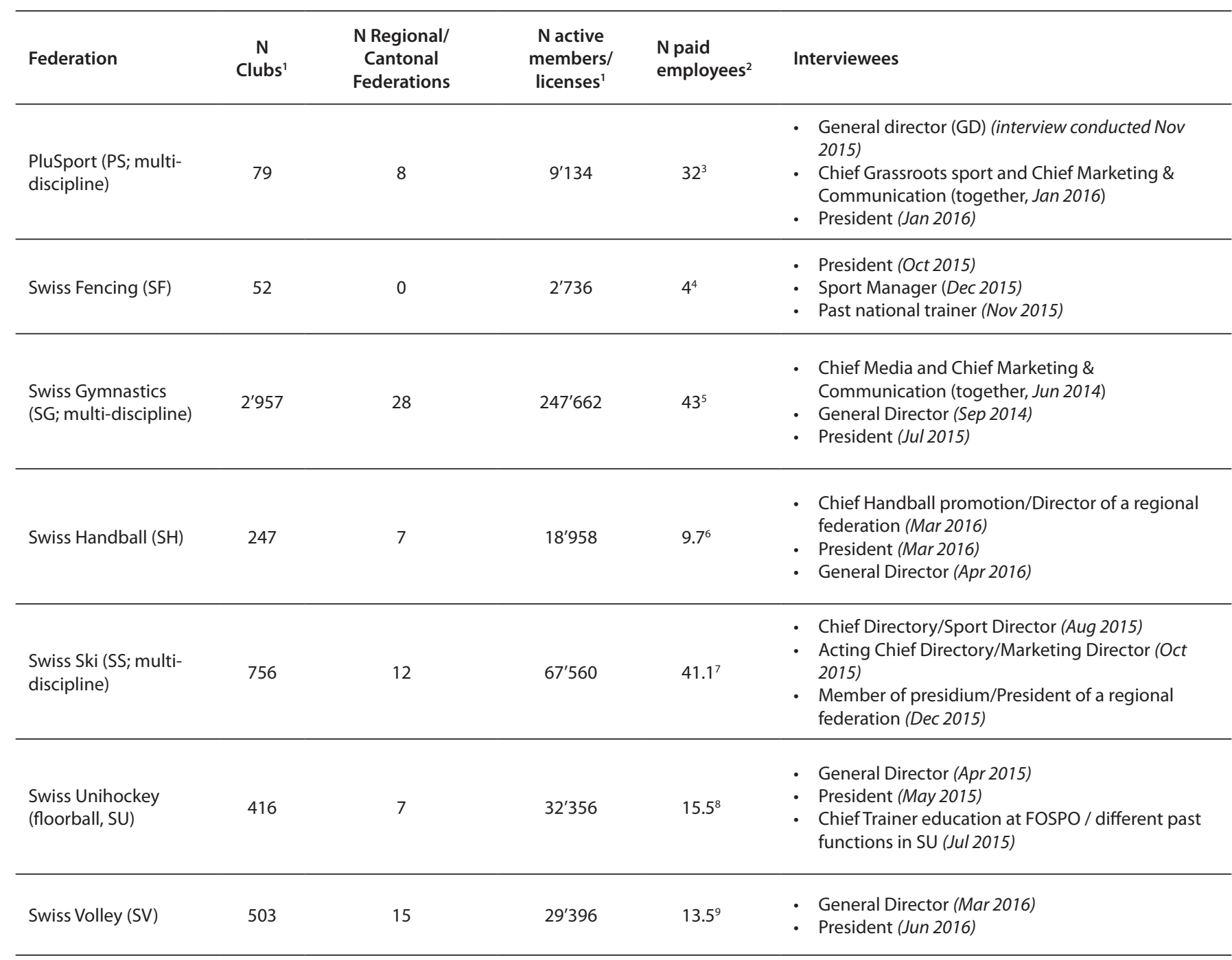

Swiss Olympic (n.d.).

2 For PluSport, Swiss Fencing, and Swiss Gymnastics the number refers to persons. For Swiss Handball, Swiss Ski, Swiss Unihockey, and Swiss Volley the number refers to full-time equivalent.

PluSport (n.d.e, p. 4)

Personal communication with President of Swiss Fencing, October 24, 2015.

State July, 2017 (Swiss Gymnastics Federation, n.d.c, Table: Der STV in Zahlen. [Swiss Gymnastics Federation in numbers]).

State June 20, 2015 (Swiss Handball Association, 2015, p. 42).

Swiss-Ski (n.d.a, p. 60).

State May 1, 2015 (Swiss Unihockey, n.d.d, p. 7)

Swiss Volley (n.d.e, p. 29). 
environment and their internal environment. NSF internal factors that were seen to have facilitated or hindered the process were noted openly. Additional information about the NSFs' professionalization was registered as well. The documents were mainly gained from the NSFs' homepages and included:

- Strategy papers and conceptions (e.g., projects, communication, also of SO)

- Annual/financial reports and protocols

- Publications (e.g., member magazines, leaflets) and media reports

The documents can be found in the references for each NSF separately. Additional documents were studied to gain an overall picture of each NSF.

Interviews. 2-4 persons from each NSF were interviewed (Table 1), face-to-face and by a minimum of two of the authors. The main criteria were the interviewee's overview of the NSF's professionalization. Thus, also persons with past positions were included. Because of further study objectives, the interview guide did not focus only on causes but also included other questions on professionalization (e.g., consequences). The frame of the interview was professionalization of the NSF to date, related strategy and challenges. Thereby, the topics were persons and positions (e.g., positions of paid staff v. volunteers), structures and processes (e.g., communication and decision-making), and strategies and activities (e.g., strategy development and evaluation). To enquire about causes for professionalization, the guide followed the three levels of the framework of Nagel et al. (2015). If not explained automatically, causes for adaptations and barriers to their implementation were asked about constantly. For example:

"What were the causes for [e.g.] hiring someone for marketing?"

"Whose initiative was [the mentioned adaptation]?"

Finally, the interviewees were asked about causes for professionalization at large, clearly referring to the three levels of the analytical framework, as well as about factors that have facilitated or hindered the NSF's professionalization. The interview guide was adapted for each NSF according to knowledge from the documents, as well as for each interviewee in consideration of the position of the interviewee (e.g., elected member/paid employee) and his/her relationship to the NSF (e.g., long-/short-term). The interviews were audio-recorded and transcribed verbatim. The average duration was 1.5 hours.

\section{Data analysis}

The data were analyzed inductively applying open coding and supported by Atlas.ti software. Open coding allows adapting dimensions of a category during the analysis and complementing the category system by knowledge derived from the material that does not suit any existing category (Gläser \& Laudel, 2010, 2013). The code-tree followed the levels of the multi-level framework of Nagel et al. (2015). Subcodes were assigned to an appropriate head code but kept close to the material. Interviews were constantly compared with previous ones and codes renamed to be more open. To reduce the code-tree, codes and codings were compared in-between and, where feasible, merged or removed. Thereby, codes for causes for professionalization were assembled adhering to the multi-level framework. In addition, NSF-specific internal factors that were deemed facilitating or hindering professionalization were gathered for each NSF separately (Appendix) and then generalized. For trustworthiness (Guba, 1981, cited in Shenton, 2004), data interpretations were reviewed by the research team, which determined reasonable final terms/characterization and presentation of the results. The interviewees had the opportunity to check the translation of their quotations. The detected causes for professionalization were roughly related to forms of professionalization that had commonly been affected by these as indicated in the empirical material (i.e., professionalization considering persons and positions, structures and processes, and strategies and activities).

\section{Results}

The results are presented for each NSF separately in three sections: NSFs endogenous causes (Table 2), and expectations from their external (Table 3) and internal environment (Table 4) that have caused professionalization in these NSF. In addition, the tables link these to particular forms of professionalization that commonly have been affected, and present additional NSFinternal factors that were found to have been facilitating for or hinder NSFs in meeting expectations from their environment for professionalization.

\section{NSFs endogenous causes}

There seem to be certain NSF-specific endogenous circumstances that cause professionalization (Table 2). From this perspective, causes for professionalization were very similar across the seven NSF and could be resumed into four groups.

Deficits in decision-making. Deficits in decision-making in the NSFs' governance and management have been a central cause for professionalization in the seven analyzed NSFs, with the goal to determine a strategic role of the board. In some NSFs, there was also mismanagement, that is, financial crisis and leaders who dominated the elected board. Consequently, for example in PS, statutes were revised, the leadership became shared between a strategic board and operative general secretary, and the organizational structure was adapted (already at the beginning of the 1990s). The General Director (GD), who had several years of experience also in the board, formalized the processes further following his "Professionalization initiative 2009". That was enabled by a progressive attitude of the board members and their trust in the GD, and relatively healthy finances. In SU, in turn, "about 4 years ago we had a board 


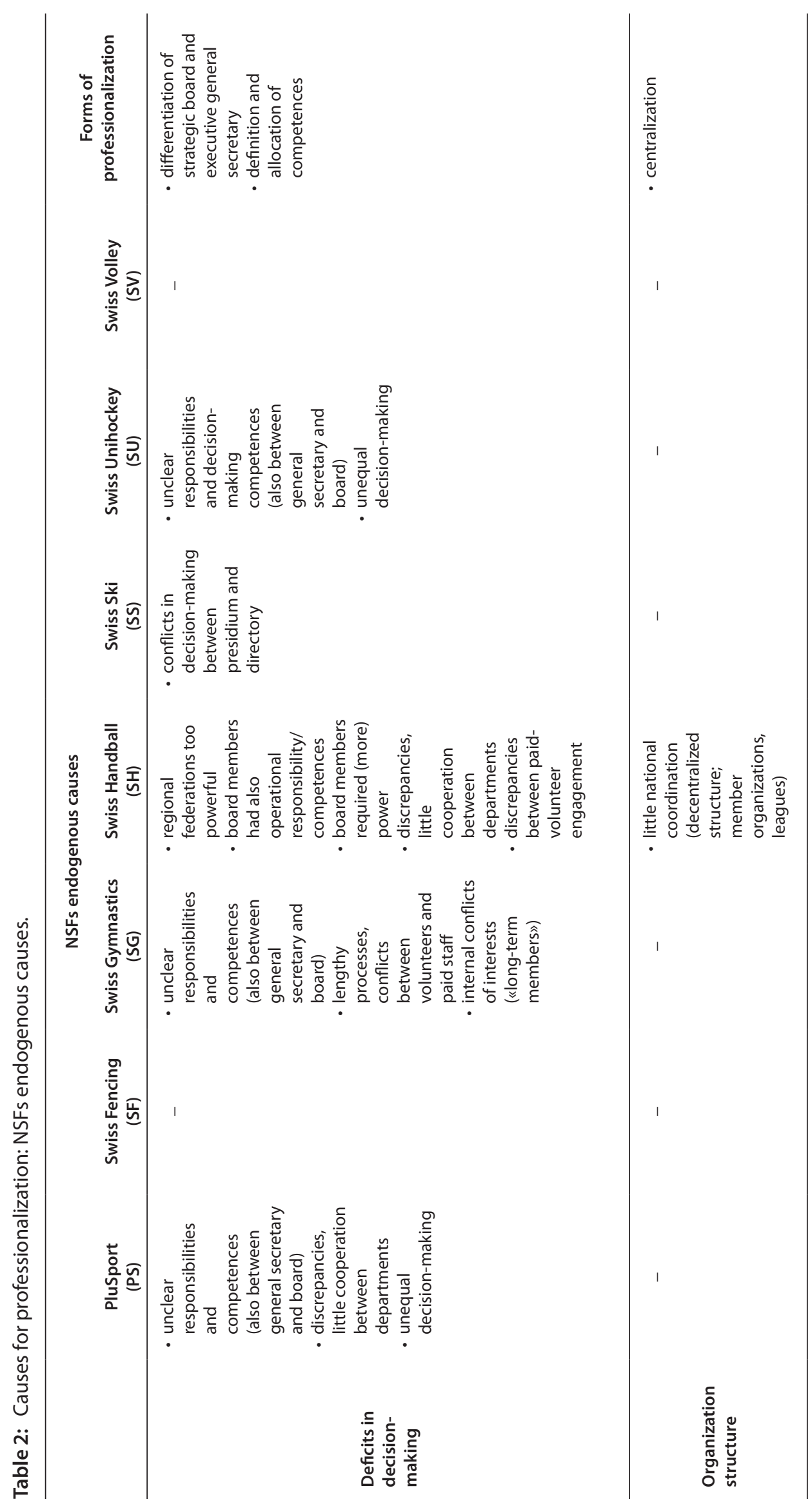




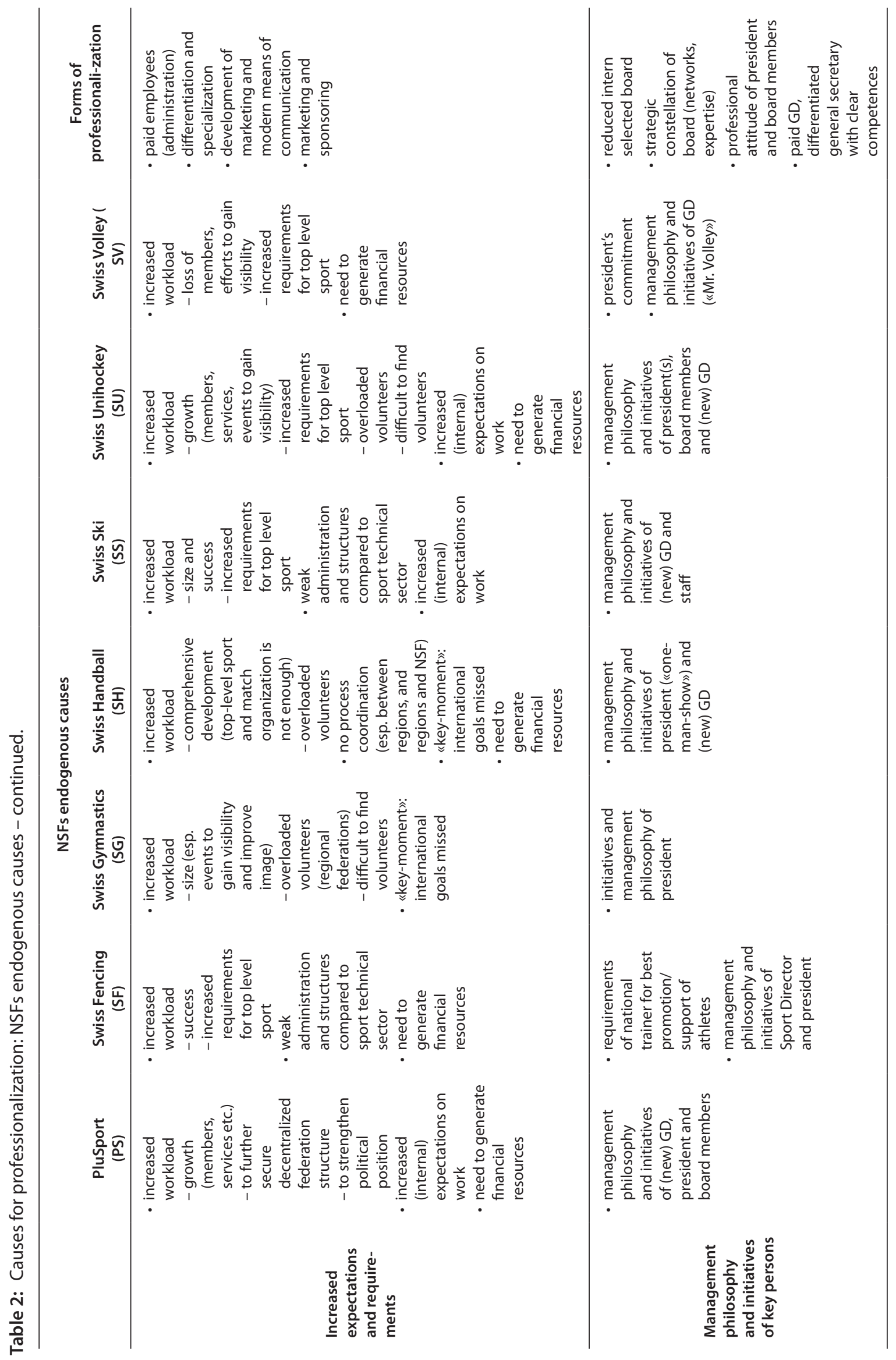


whose members actually have done a lot for the development of floorball, but who also claimed a great deal of decision-making competences" (SU president). However, in several cases, competences still cause conflicts within the boards as well as between them and current paid GDs, impeding organizational changes. In case of SG, after first initiatives more than 20 years ago, the delegates accepted a statute revision not earlier than 2006. However, taken out from the strategy 2014-2019 - and claimed by the interviewees, too - responsibilities and competences are not entirely clear.

Organization structure. In $\mathrm{SH}$, professionalization was put in process because of inadequate federation structure that hindered cooperation and efficient operation: "There was neither a General Director nor was the federation otherwise lead, the president took over intermittently, the departments worked in their own silos... often, the staff couldn't be found in the offices and there were no regular meetings" (SH GD).

Activities of regions and clubs were not nationally coordinated. Consequently, the NSF established a more harmonized general secretary and centralized the NSF structure - at the end top down - to standardize processes to be more efficient. In SV, in turn, efforts to reduce regional federations; were not approved by the member organizations.

Increased expectations and requirements. Overall, through professionalization, the analyzed NSFs strive for professional structures and conditions for athletes and clubs to be internationally successful: "In top-level sport, you have to be a professional player, and professional management is required not only for the athletic part, but the same is true for the marketing part, for handball development etc." (SH president). In some NSFs, failures of national teams had been the key moment for starting professionalization, whereby the new benchmarks make the work more challenging. Increased expectations for quality of work (e.g., people's qualifications) within the NSF but also relationships with different stakeholders have forced the NSF to build departments, staff, strategies, etc., to better merchandise their sport and thus generate financial resources. At the same time, restricted financial resources have slowed down or hindered professionalization in various areas (e.g., employment of paid staff).

Also, growth of NSFs, including events and services for member organizations, has increased work and complexity of tasks, which NSFs intend to manage by professionalization: "We offer much more services...so, we said, we would professionalize the federation regarding marketing and communication, and then we established this paid position" (PS M\&C).

In $\mathrm{SF}$, national trainers had driven professionalization in the federation for years. Under a constantly changing board until 2005 without any common vision, resources were put into sport and indispensable administration, disregarding organizational structures. This was possible because of the confidence from $\mathrm{SO}$ in the federation's international success. However, because of increasing success, managing the federation became increasingly time-consuming and complex. Thus, it became impossible for the trainers to further manage "federation's issues that were no concern of mine" (SF past-trainer). Ultimately, organizational structures, responsibilities and administration were insufficient to manage the sport. The same applies to SS. Key persons and management philosophy. The data showed a high relevance of key persons' management philosophy. In several cases, it was dissatisfaction of board members that caused the first moves toward professionalization: "one-manshow" (SH Regional Director), "double-head leadership" (PS GD) caused uproar, leading to deselections and reduced boards. To form a strategically capable board, the NSFs pay attention to the volunteers' expertise in the private sector (leading positions), as well as networks: "It doesn't make sense to have five persons from the basis [in the board] and none of them understands anything about finance" (PS Chief Grassroots). NSF boards seem to ensure a "professional" attitude at work by recruiting board members through personal networks. As an exception, SF highly values a fencing background.

At the headquarters, in turn, differentiation and specialization have commonly been driven by management philosophy of GDs that they bring in from the private economy: "What I changed was the organizational structure with clear responsibilities for everyone, especially for the management team...The management team has to be empowered to have a clear and strong position vis-a-vís the board" (SV GD). Also, specific and more recent changes concerning daily processes to support strategy development are introduced by paid staff, particularly the GD. The implementation, however, mostly requires the acknowledgment of the board. The NSFs have implemented little process coordination so far, which can be hindering for further federation development, because many tasks are done "ad hoc." However, management and monitoring tools are under development in the NSFs. In contrast to the other NSFs, in SF it was a national team trainer and sports director, who initiated and drove professionalization until 2008, when they were released by the new president from administrative tasks.

\section{Expectations of stakeholders in sport and society (external environment)}

Professionalization has been triggered also by NSFs' relationships with actors from their external environment (Table 3). Mostly, NSFs receive financial support only, when they fulfill the requirements placed by the state and other stakeholders. As explained above, Swiss NSFs operate widely autonomously. However, there are some concepts stipulated by the Confederation that apply to all. FOSPO conducts most of them in cooperation with SO. Business partners and media have also caused particular forms of professionalization, whereby NSFs' positions in these relationships differ.

State and policymaker. The societal meaning and democratic organization of sport obliges Swiss NSF to establish further services for kids and grassroots sport. In addition, because of the meaning of sport in the international context, FOSPO 
Table 3: Causes for professionalization: NSFs' external environment.

\begin{tabular}{|c|c|c|c|c|c|}
\hline & \multicolumn{3}{|c|}{ Expectations of stakeholders in sport and society } & \multirow{2}{*}{$\begin{array}{c}\text { Forms of } \\
\text { professionalization }\end{array}$} & \multirow{2}{*}{$\begin{array}{l}\text { NSF-internal facilitating } \\
\text { and hindering factors }\end{array}$} \\
\hline & PluSport (PS) & Swiss Fencing (SF) & $\begin{array}{c}\text { SG, SH, SS, } \\
\text { SU, SV }\end{array}$ & & \\
\hline $\begin{array}{l}\text { Government } \\
\text { and policy } \\
\text { maker } \\
\text { (FOSPO) }\end{array}$ & $\begin{array}{l}\text { - requirements for } \\
\text { efficient sport } \\
\text { promotion and } \\
\text { spending of } \\
\text { funds } \\
\text { (FOIS, ZEWO) }\end{array}$ & $\begin{array}{l}\text { - expectations on } \\
\text { young athletes' } \\
\text { promotion }\end{array}$ & $\begin{array}{l}\text { - expectations on } \\
\text { young athletes' } \\
\text { promotion }\end{array}$ & $\begin{array}{l}\text { - concepts for sports } \\
\text { promotion } \\
\text { - expanded general secretary } \\
\text { (paid staff, differentiation, } \\
\text { specialization) } \\
\text { - output measurement, } \\
\text { auditing }\end{array}$ & \multirow{2}{*}{$\begin{array}{l}\text { facilitating factors } \\
\text { - solid finances } \\
\text { - success } \\
\text { - sponsor relationships } \\
\text { hindering factors } \\
\text { - scarce financial resources } \\
\text { - invisibility in the media } \\
\text { - overloaded staff and } \\
\text { volunteers } \\
\text { - lack of transparency / } \\
\text { resistance of member } \\
\text { organizations }\end{array}$} \\
\hline Swiss Olympic & - & $\begin{array}{l}\text { - performance } \\
\text { agreement } \\
\text { - auditing system }\end{array}$ & $\begin{array}{l}\text { - performance } \\
\text { agreement } \\
\text { - auditing system }\end{array}$ & $\begin{array}{l}\text { - documentation of strategy, } \\
\text { implementation and } \\
\text { governance structure } \\
\text { - output measurement, } \\
\text { auditing }\end{array}$ & \\
\hline
\end{tabular}

has established a program for sustainable top-level athlete promotion. That, in turn, enables NSFs to create professional training conditions for athletes, which the NSFs otherwise could not offer (e.g., additional paid positions).

Although a SO member, PS, whose main aim is integration of people with disabilities, is not supervised by SO but the Federal Office for Social Insurance (FOIS) and Swiss Charity Monitoring (ZEWO). The requirements of FOIS seem very similar, including performance agreements and a specific auditing system. However, the subsidies are prescribed for services and distributed to the clubs, whereas top-level sport is funded by SO. Recently, FOIS has begun requiring accounting for each club and service separately. That prompted PS to create a position responsible for the clubs' accounting, because they cannot handle it by themselves. So far, PS has no output measurement instruments - "we did not have to have that" (PS GD) - but has to invest in such tools now, because FOIS plans to switch from performance agreements to an efficacy orientation.

Umbrella organization Swiss Olympic. In the preamble of the federation promotion concept SO writes: "In the strategy of SO of 2012, the support and strengthening of the member federations as a service provider...[is] the highest legitimation of SO." Performance agreements are a central element of federation promotion. Therewith, SO has considerable impact on NSFs' professionalization. For SO, the agreements are "a long-term strategy... securing the planning for $\mathrm{SO}$, as well as for the NSF" (Swiss Olympic, 2013, p. 4). "Eligibility for promoting" of the NSFs depends on the respective grading, and their financial resources determine their "capability for promoting" (ibid). Because of these obligations, NSFs have to present 4-years-strategies, which had been - if existing at all - vague in some, even bigger NSF so far.

The federation promotion concept "should not consider only high-level sports, but has to include also leadership and ethics in an adequate manner" ("completeness"), and "the selfresponsibility and scope of design of the member federations are to be acknowledged and reinforced" ("autonomy ") (Swiss Olympic, 2013, Preamble). Despite "some additional laps", the NSFs understand the requirements of SO and welcome the transparency between all actors, for, "if you want grants, you have to do some adaptations and you just do it" (SV GD). As explained before, in SF, there was clearly a need for new structures and adaptation of processes to ensure appropriate management of the sport. However, it was only after pressure by SO that necessary actions were taken:

[SO] animated us to improve the headquarter structures and administration ... First I was against this system, because they forced us into additional expenditures ... At the end, they were right; after optimizing the administration, we could generate resources to gain funds better, use the systems, we rationalized and made them more efficient. At the end, it costs, but we still benefit. (SF president)

Autonomy of NSFs in strategy implementation may to some extent explain why, despite the contracts and similar concepts that all NSFs need to fulfill, professionalization and current designs differ between NSFs. The implementation then 
depends on, for example, financial and human resources, or the role of member organizations, which tend to be more critical of the need of such concepts.

Business partners and media. Sponsors and media partners undeniably impact professionalization of all analyzed NSFs. The president of SH wrote in the Annual Report of 2012/13: "I've previously pointed to the international professionalization and related commercialization, new approaches of national sponsors in grassroots sport,... and the fully altered communication environment" (Swiss Handball Association, 2013 , p. 29). The main aim of business partnerships is to generate financial resources for building the best possible training conditions to promote international success and guarantee NSFs' function as umbrella organizations. SH, SU and SV seek visibility via platforms, such as well-showcased events, to attract people and ensure sustainability: "Best sustainability is when we get young players to a big event saying 'Wow, that's what I want'. Now I'll go and train more'" (past-SU/FOSPO).

In business partnerships, NSFs are bound to diverse organizational adaptations (apart from SF, which perceives no pressure from sponsors, because these support athletes), such as hiring qualified people for marketing and public affairs. "A great amount of the money [from the sponsor] goes into communication [to present the sponsor]" (SH president). However, GD of SH says, "respective structures, such as centralized marketing systems, are necessary" to manage the requirements of sponsors efficiently. As a reaction to the exponential event expansion of the NSFs, PS, for example, extended event development and hired an additional person "to serve the media more specifically and to build a network" (PluSport, n.d.d, p. 10). Somewhat ambivalently, business partners may require a contact person, or someone for marketing.

The positions of the analyzed NSFs on the market differ, because sports that are little noticed in society are less attractive for media and sponsors. The NSFs seem willing to follow the requirements of business partners - or they may have no choice. Since media and sponsors are needed for securing all kinds of resources, for NSFs that are hardly visible, to adapt to present needs appears difficult and can be done only in small steps. The mutual sponsor of the team sports SU, SH and SV (Mobiliar; an insurance provider) has not only required professionalization, but even supported the NSFs in the process. The relationship has brought them far more than financial resources. It has helped the NSFs to improve their performance (e.g., event organization) and thus significantly contributed to their popularity and visibility.

We've been lucky with Mobiliar, we basically got it without any investment. They basically found us, which is rare in sport. It was a milestone [in professionalization of SU]; how they've supported us and brought us popularity, made us presentable, with innovative good ideas, the whole entertainment framework. I think, we got a lot...and made an incredible impact, what was possible only thanks to them. (past-SU/FOSPO)
SU, SH, SV and the Swiss basketball federation established a stock corporation on the initiative of Mobiliar - "a really professional partner" - to "act as counterbalance to ice hockey, soccer, skiing" (SV president). For bigger platforms for all actors, the four NSFs guarantee Mobiliar professional communication and more consumer services, such as player statistics, in return. SS and PS have attracted business partners for many years. Thus, compared to the five other NSFs, they are more empowered in those relationships. Especially alpine skiing is very popular in Switzerland, whereas PS, although until recently unknown even in politics, has always profited from a "disability bonus"; "disability sport is attractive, young, dynamic, it appeals to people to donate" (PS Chief M\&C). Solid finances have enabled PS to enhance professionalized services to their member organizations and respond better to environmental changes. SS, in turn, has concentrated its resources into professionalization of marketing and event organization, including paid staff.

Relationship with and expectations of member organizations (internal environment)

Little professionalization in NSFs has been caused directly by member organizations. Some NSFs, especially PS, SG and $\mathrm{SU}$, have been forced to professionalize the relationship with their dissatisfied member organizations. The visions drifted apart and member organizations felt overrun in the strategy and federation development. This is manifest in the following example:

They were dissatisfied with the voluntary disciplinary committee, the decision-making takes too long... dissatisfied with the new homepage.....And then, the clubs complain "when we once deliver delayed match reports, we get fined. My dear federation, the homepage still isn't updated. Do you get a fine, too?" (SU president)

Interviewees from other NSFs also stated that the member organizations have been neglected in federation development. Their dissatisfaction and mistrust became evident as NSFs have made the tasks more demanding for their member organizations (through new process management, larger headquarters, steering instruments, etc.) to finally address these as "their needs." Hence, in the course of NSFs' professionalization, member organizations feel that they too have the right to express higher expectations. However, the common drivers for the professionalization of service delivery for clubs and regions are employees at the headquarters. Being aware of the volunteer basis and scarce resources of the member organizations, the NSFs "have to find a balance between the needs of the volunteers, who do their work with enthusiasm as a hobby, and a professional appearance" (SG GD). Once NSFs realized that the clubs lacked the time and expertise to address the growing demands, they hired employees to support the clubs: "It's clear that twice the number of camps [for club members] means more work. We realized that we've missed out on the club support so far and hired 


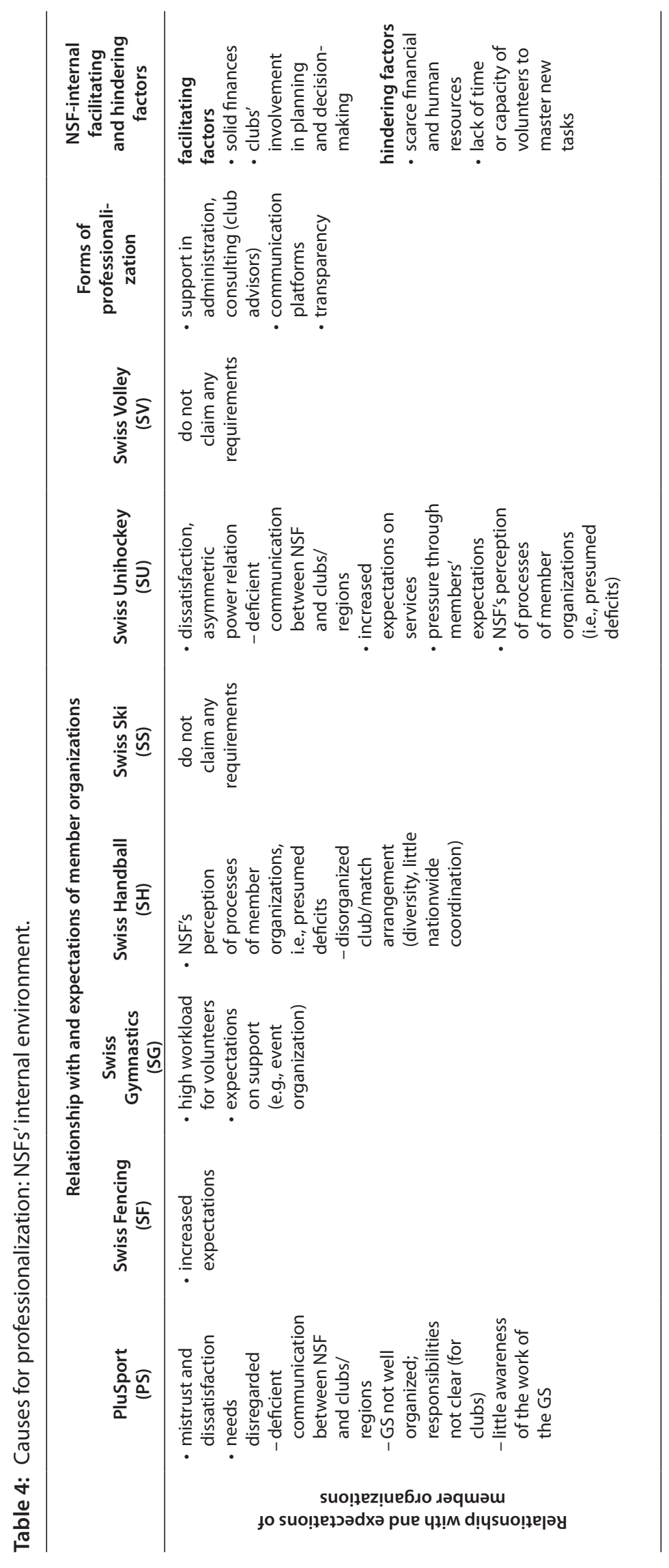


now two persons who literally go to the clubs" (PS Chief Grassroots sport). Other expectations of the clubs concern mostly services to their members and expectations from media and the public (e.g., social media, good event organization). Our analysis did not show intentions of NSFs regarding headquarters, decisionmaking, or evaluation/steering tools that were not fulfilled because of resistance of member organizations. Transparent communication is the key to avoiding resistance against further professionalization.

\section{Discussion}

This study explored causes for professionalization in seven Swiss NSFs, based on a three-level framework for analyzing causes for professionalization (Nagel et al., 2015). Although the NSFs differ, for example, in size, organizational structures, and international resonance, causes for their professionalization have been widely similar. Thereby, causes at external and endogenous level seem to influence each other reciprocally and are hard to distinguish. NSF-specific conditions, particularly financial and human resources, popularity of the sport and (striving) attitude of individuals towards professionalization seem to have an additional impact on NSFs' capability to respond to external expectations.

\section{Theoretical reflection of the findings}

Referring to the similarity of causes for professionalization - besides external pressure - competing for resources and uncertainty may have led some NSFs to mimic and model themselves on those NSFs that they deem successful, leading to similar conditions (e.g., with respect to workload and internal expectations) that call for professionalization (DiMaggio \& Powell, 1983). It is also conceivable that shifts in societal norms have influenced the thinking of board members, leading them to transfer their management perspective from the private sector into the NSF (O'Brien \& Slack, 2003), reflected, for example, in domains ascribed to each board member. However, the conceptions that strategy makers have of an appropriate umbrella organization seem to be "initial bursts of change" and deficits in decision-making "high-impact-elements" that, due to their symbolic role in effective functioning of an organization, are preferably adapted early for further professionalization process (Amis, Slack, \& Hinings, 2004a). Such conditions are independent of the NSF's size, as is increase in workload, which emerges as a side-effect of international success and maintenance of it (O'Brien \& Slack, 2004), on the one hand, and from internal and external requirements for the quality of work, on the other hand.

Our study contributes to knowledge of causes for often takenfor-granted institutional arrangements and practices that legitimize the "new" organization, and thus to perspectives of institutional theories of how fields of sport organizations are constituted and how their environment affects their characteristics (Washington\& Patterson, 2011).Theexpectations on professionalization from NSFs' external environment reflect general trends in society, such as the meaning of entertainment, the weight of performance measurements (Bayle \& Robinson, 2007; Macris \& Sam, 2014) and rationalization, and seem to be aimed at demonstrating professional NSFs (Hwang \& Powell, 2009). The state has also become more efficiency-orientated and expects evidence for the use of funds, the result of which is that personal relationships and trust no longer suffice. This is particularly implicated in the requirements for PS that are in line with those of the other NSFs, although PS is answerable to other funders (social insurance) and its scope of service (social integration) differs from the other NSFs.

Resource dependence theory recognizes organizations as intentionally operating actors that are not able to perform their activities without resources from their environment (Pfeffer \& Salancik, 2003). That implies social mechanisms and makes the theory a helpful supplement to institutional mechanisms. As we saw, the institutions that exert coercive pressure on the NSF tend to be the ones on which NSFs commonly depend (Edwards et al., 2009; Vos et al., 2011). We may ask whether causes for professionalization can be discovered - retrospectively, per se - or whether we should focus on the reasoning, rationale and aims of (organizational) actors behind professionalization of NSF and support institutionalist approaches with, for example, resource dependence theory. Such a perspective is missing in the present analytical framework. It could, however, support analysis of both intended and unintended consequences of professionalization, such as the risk that, when budget allocation is strictly dependent on performance, NSFs concentrate as much on the relationship with the contributor as on real improvement of their performance (Gilmour, 2007, as cited in Macris \& Sam, 2014). Continuous adaptations as such may also run into legitimacy problems, contrary to the goal of professionalization (DiMaggio \& Powell, 1983; Macris \& Sam, 2014).

Expectations from NSFs' member organizations evolved from umbrella federations' professionalization, rather than triggering it as suggested by Nagel et al. (2015). Furthermore, the NSFs postulated clubs necessities that the clubs themselves did not perceive. For efficient use of resources, stakeholders should keep an eye on necessities and assumptions in the NSF. The discrepancies could result from a certain collision of "sports-for-all" logic promoted by the sport movement itself with commercialization and performance measurement of competitive sports (Stenling \& Fahlén, 2009). A specialized club advisor, now established in some NSFs, may elude demands that clubs raise following the requirements of the NSF. However, conversion to a service provider bears the risk that NSFs to some extent neglect their duty to advocate the clubs' interests. Our analysis confirms that transparent communication to reduce information asymmetries between umbrella and member organizations are of utmost importance (Amis, Slack, \& Hinings, 2004b; Ferkins \& Shilbury, 2010). Club supporters as "buffers" could help sport clubs to continue with a community- 
oriented sport and professionalize only to a certain degree compared to the competitive sport part of the NSF (Ferkins, Shilbury, David, \& McDonald, 2005; Skille, 2009), also in terms of warranting clubs' autonomy. Principal-agent theory could be a useful approach to address the meaning of professionalization for member organizations together with the role of the NSFs as agents driving their interests, to contribute to more symmetry in the relationship. It could address, for example, factors that promote mechanisms to ensure symmetry (e.g., securing shared values, defining short-term goals) or issues that both parties deem appropriate to be required from paid staff/ umbrella organizations and vice versa.

\section{Reflection on the multi-level framework for analyzing professionalization in NSFs}

The framework of Nagel et al. (2015) appears too simplified for an analytical framework, and it does not capture factors that influence professionalization once it first has been initiated nor interrelationships between the levels. The analysis of seven Swiss NSFs revealed though that professionalization is continuously influenced by factors that apply to the NSF unequally but are essential to meet expectations from the external and internal environment. Considering plainly which actors or circumstances bring about professionalization disregards a dynamic process of varying pace, directions and possibly throwbacks. Definition of competences between a strategic board and operative general secretary, for example, has been an initial goal of professionalization. However, in several cases these still cause conflicts. Referring to our findings, several circumstances that the multi-level framework deems as causing professionalization seem rather factors that would have an influence on the nature and pace of an ongoing process (e.g., financial resources), or factors that have a considerable influence on first gaining these resources (e.g., size, media). These factors seem to be in line with internal situational characteristics that research applying contingency approach has considered as barriers or facilitators for professionalization (Horch \& Schütte, 2009). Scarce financial resources may trigger professionalization when the NSF begins to restructure the organization to optimize efficiency. However, financial resources play an essential role in allowing professionalization to be brought about, as has been discovered also in previous studies (e.g., Welty Peachey et al., 2015). SS, SF and PS ("disability bonus") appreciate the profit they have from solid finances for professionalization. SS and SF are not the only NSFs with disciplines in the highest category of SO (i.e., internationally successful); however, additional revenue from sponsoring (SS) and "advantageous stance" towards SO (SF) may have strengthened their favorable financial situation. NSFs of less popular sports invest in marketing and communication, because they struggle with the interdependence of success in sport and attractive preconditions, that is, presence, interest of media and sponsors and financial resources, whereby the last two affect the conditions for the first two - and the chain closes. Since similar conditions, plus structures and strategic concepts determine subsidies from SO, NSFs' internal efforts may not be sufficient for professionalization. Or, the NSFs may not be strong enough to argue against it.

\section{Limitations and future studies}

This study has some limitations. Our subjective perception of Swiss NSFs may have influenced the selection of the cases, excluding less professionalized federations. Although our analysis reached back to a time when the NSFs operated in a straightforward manner and mostly voluntarily, our data may still miss information about all barriers to eventual professionalization initiatives faced by the NSFs. To better understand barriers - or reasoning for not approaching professionalization - future studies could focus only on less professionalized NSFs. The selection of the interview partners could have biased the (prominent) role of individuals in professionalization. Being familiar with the NSF's professionalization could mean that they also perceive an essential role of themselves in the NSF's development, especially in seemingly successful cases (Freitas, Girginov, \& Teoldo, 2017). Nevertheless, the interviewees traced professionalization back to diverse persons, not necessarily themselves, confirming a central role of persons in different positions initiating and driving professionalization. The same was evident for the restricting role of key persons. These results remind us that we should also consider theories other than organizational ones in NSF studies; for example, social identity theories (e.g., what role do the differences between the identities of a board member, who is passionate about sport, and an employee, whose identity reflects a manager's role, have for strategy development?), or the leader-memberexchange theory (e.g., what would be the best indicators of a relationship with the most productive potential between club presidents and employees at the headquarter?) (cf. Todd, Andrew, \& Sowieta, 2009). Since professionalization is mostly deemed a desirable process of modern organizations, social desirability of informants must be considered: besides personal impact, interviewees may be interested in the good reputation of their NSF. This issue we addressed by including persons of different, also past, positions, with shorter and longer history in the NSF, persons who also have criticized the development, as well as documents. Also, it is possible that interviewees are open about past deficits to emphasize positive development. Nevertheless, a retrospective view can distort one's perception of causes for professionalization. Thus, our interviewees may have rationalized it retrospectively with endogenous causes, although external pressure would have been crucial, such as the requirements of SO regarding the level of grants (e.g., Chief Sports, talent development concepts). Longitudinal observations would be useful to eliminate false rationalization of change by the interviewees, as well as to better consider "emergent changes" in organizations that may have no causal explanation (Smith, 2004). Furthermore, we acknowledge the 
issue of generalizability of the results from the Swiss context. However, they present a good starting point for analyzing causes for professionalization and factors that have a further impact on the process in other countries.

Further research is needed to investigate forms of professionalization in more detail and to discover causes and barriers - for more or less successful professionalization. Research should not disregard unintended consequences of professionalization. The question of whether professionalization leads to more effective outcomes, or whether it is a rationalized "institutional myth" (Meyer \& Rowan, 1977) should be addressed. Single-case studies could be useful to understand more clearly the mechanisms, potential phases, to avoid unintended consequences. This may be of interest for SO and the Swiss NSF, too, to optimize the development of clubs and support for athletes.

\section{Conclusion}

The endogenous and external causes for professionalization in Swiss NSFs seem to be interdependent resulting in a reciprocity of the same. Although Swiss NSFs are widely autonomous, they can be steered by the state and SO. Since professionalization is costly, and in order to improve their activities, NSFs remain dependent on their external environment, which is increasingly demanding. However, there are NSF-specific factors that allow (or hinder) professionalization to be advanced as expected from NSFs' external and internal environment. These may be added by SO to considerations for allocating subsidies. Networks between stakeholders and key actors in the NSF could be an appropriate strategy for avoiding barriers and completing a deliberate professionalization of intended outcomes. Our analysis is a first step towards understanding professionalization processes in Swiss NSFs. Knowing the factors that have triggered NSFs to change their structures and processes can help advisors accompanying Swiss NSFs, as well as NSF managers, to scrutinize the necessity of changes and avoid unintended consequences, and thus support NSFs' development in an efficient manner.

\section{Acknowledgment}

We would like to thank Roman Brühlmann, Reto Büchi, Piet Heer, Lorena Müller and Paul Wyrsch for their valuable support in data collection.

\section{Funding}

This work was supported by Swiss National Science Foundation [100017_129563/1].

\section{Competing Interests}

The authors have declared that no competing interests exist.

\section{Data Availability Statement}

All relevant data are within the paper.

\section{References}

Amis, J., Slack, T., \& Hinings, C. R. (2002). Values and organizational change. The Journal of Applied Behavioral Science, 38, 436-465.

Amis, J., Slack, T., \& Hinings, C. R. (2004a). The pace, sequence and linearity of radical change. Academy of Mangement Journal, 47, 15-39. doi:10.2307/20159558.

Amis, J., Slack, T., \& Hinings, C. R. (2004b). Strategic change and the role of interests, power and organizational capacity. Journal of Sport Management, 18, 158-198. doi:10.1123/ jsm.18.2.158.

Bayle, E. (2017). Switzerland: The organisation of sport and policy towards sport federations. In J. Scheerder, A. Willem, \& E. Claes (Eds.), Sport policy systems and sport federations. A cross-national perspective (pp. 263-282). UK: London: Palgrave Macmillan.

Bayle, E., \& Madella, A. (2002). Development of a taxonomy of performance for national sport organizations. European Journal of Sport Science, 2, 1-21. doi:10.1080/17461390200072205.

Bayle, E., \& Robinson, L. (2007). A framework for understanding the performance of national governing bodies of sport. European Sport Management Quarterly, 7, 249-268. doi:10.1080/16184740701511037.

Chantelat, P. (2001). La professionnalisation des organisations sportives: Nouveaux débats, nouveaux enjeux [Professionalisation of sport organisations: new debates, new challenges]. Paris: L'Harmattan.

Chappelet, J.-L. (2010). Switzerland. International Journal of Sport PolicyandPolitics,2,99-110.doi:0.1080/19406941003634065.

Child, J., \& Rodrigues, S. B. (2011). How organizations engage with external complexity: A political action perspective. Organization Studies, 32, 803-824. doi:10.1177/0170840611410825.

Dart, J. (2014). Sports review: A content analysis of the International Review for the Sociology of Sport, the Journal of Sport and Social Issues and the Sociology of Sport Journal across 25 years. International Review for the Sociology of Sport, 49, 645-668. doi:10.1177/1012690212465736.

DiMaggio, P. J., \& Powell, W. W. (1983). The iron cage revisited: Institutional isomorphism and collective rationality in organizational fields. American Sociological Review, 48, 147-160.

Doherty, A., Misener, K., \& Cuskelly, G. (2014). Toward a multidimensional framework of capacity in community sport clubs. 
Nonprofit and Voluntary Sector Quarterly, 43, 124-142. doi: 10.1177/0899764013509892.

Dowling, M., Edwards, J., \& Washington, M. (2014). Understanding the concept of professionalisation in sport management research. Sport Management Review, 17, 520-529. doi:10.1016/j.smr.2014.02.003.

Edwards, J.R., Mason, D.S., \& Washington, M. (2009). Institutional pressures, government funding and provincial sport organisations. International Journal of Sport Management and Marketing, 6, 128-149. doi: 10.1504/IJSMM.2009.028798.

Evetts, J. (2011). Professionalism and management in public sector: challenges and opportunities. In A. Langer \& A. Schröer (Eds.), Professionalisierung im Nonprofit Management [Professionalization in non-profit management] (pp. 33-44). Wiesbaden: Springer VS.

Ferkins, L., \& Shilbury, D. (2010). Developing board strategic capability in sport organisations: The national-regional governing relationship. Sport Management Review, 13, 235-254. doi:10.1016/j.smr.2010.01.009.

Ferkins, L., Shilbury, David, \& McDonald, G. (2005). The role of the board in building strategic capability: Towards an integrated model of sport governance research. Sport Management Review, 8, 195-225.

Freitas, D., Girginov, V., \& Teoldo, I. (2017). What do they do? Competency and managing in Brazilian Olympic sport federations. European Sport Management Quarterly, 17, 193209. doi:10.1080/16184742.2016.1244697

Gläser, J., \& Laudel, G. (2010). Experteninterviews und qualitative Inhaltsanalyse [Expert interviews and qualitative content analysis] (4th ed.). Wiesbaden: VS Verlag.

Gläser, J., \& Laudel, G. (2013). Life with and without coding: Two methods for early-stage data analysis in qualitative research aiming at causal explanations [96 paragraphs]. Forum Qualitative Sozialforschung / Forum: Qualitative Social Research, 14, Art. 5. Retrieved 11.4.2017 from http://nbn-resolving.de/ urn:nbn:de:0114-fqs130254

Guba, E. G. (1981). Criteria for assessing the trustworthiness of naturalistic inquiries. Educational Communication and Technology Journal, 29, 75-91.

Horch, H. D., \& Schütte, N. (2009). Pressure and obstacles to the employment of paid managers in voluntary sports clubs and federations in Germany. European Journal for Sport and Society, 6, 101-120. doi:10.1080/16138171.2009.11687832

Hwang, H., \& Powell, W. W. (2009). The rationalization of charity: The influences of professionalism in the nonprofit sector. Administrative Science Quartely, 54, 268-298. doi:10.2189/ asqu.2009.54.2.268

Kikulis, L. M. (2000). Continuity and change in governance and decision making in national sport organizations: Institutional explanations. Journal of Sport Management, 14, 293-320. doi:10.1123/jsm.14.4.293

Kikulis, L. M., Slack, T., \& Hinings, C. R. (1995). Toward an understanding of the role of agency and choice in the changing structure of Canada's national sport organizations. Journal of Sport Management, 9, 135-152. doi:10.1123/jsm.9.2.135
Kriesi, H., \& Trechsel, A. H. (2008). The politics of Switzerland: Continuity and change in a consensus democracy. Cambridge: Cambridge University Press.

Legay, A. (2001). La professionnalisation de l'emploi associatif [The professionalisation of employment in voluntary organisation]. Marseille: CÉREQ.

Macris, L. I., \& Sam, M. P. (2014). Belief, doubt, and legitimacy in a performance system: national sport organization perspectives. Journal of Sport Management, 28, 529-550. doi:10.1123/jsm.2012-0290

Maier, F., Meyer, M., \& Steinbereithner, M. (2016). Nonprofit organizations becoming business-like: a systematic review. Nonprofit and Voluntary Sector Quarterly, 45, 64-86. doi:I0.1177/0899764014561796

Meyer, J. W., \& Rowan, B. (1977). Institutionalized organizations: Formal structure as myth and ceremony. The American Journal of Sociology, 83, 340-363.

Nagel, S., Schlesinger, T., Bayle, E., \& Giauque, D. (2015). Professionalisation of sport federations - a multi-level framework for analysing forms, causes and consequences. European Sport Management Quarterly, 15, 407-433. doi:10.1080/161 84742.2015.1062990

O'Brien, D., \& Slack, T. (2003). An analysis of change in an organizational field:The professionalization of English rugby union. Journal of Sport Management, 17, 417-448. doi:10.1123/ jsm.17.4.417

O'Brien, D., \& Slack, T. (2004). The Emergence of a professional logic in English Rugby Union: The role of isomorphic and diffusion processes. Journal of Sport Management, 18, 13-39. doi:10.1123/jsm.18.1.13

Pfeffer, J., \& Salancik, G. R. (2003). The external control of organizations: a resource dependence perspective. Stanford: Stanford University Press.

PluSport (n.d.d). Jahresbericht 2015 [Annual Report 2015]. Retrieved from https://www.plusport.ch/de/plusport/\#c3959

PluSport (n.d.e) Jahresbericht 2016 [Annual Report 2016]. Retrieved from http://www.plusport .ch/plusport/jahresbericht/ archiv.html

Ruoranen, K., Klenk, C., Schlesinger, T., Bayle, E., Clausen, J., Giauque, D., et al. (2016). Developing a conceptual framework to analyse professionalization in sport federations, European Journal for Sport and Society, 13, 55-74. doi:10.1080/1613817 1.2016.1153881

Swiss Gymnastics Federation (n.d.c). Über uns [About us]. Retrieved September 14, 2017, from www.stv-fsg.ch/de/verband/ueber-uns/

Seippel, Ø. (2002). Volunteers and professionals in Norwegian sport organizations. Voluntas, 13, 253-270. doi:10.1023/A:1020389409852

Shenton, A. K. (2004). Strategies for ensuring trustworthiness in qualitative research projects. Education for Information, 22, 63-75. doi:10.3233/EFI-2004-22201

Skille, E. Å. (2009). State sport policy and voluntary sport clubs: The case of the Norwegian sports city program as social 
policy. European Sport Management Quarterly, 9, 63-79. doi:10.1080/16184740802461736

Skinner, J., Steward, B., \& Edwards, A. (1999). Amateurism to professionalism: Modelling organisational change in sporting organisations. Sport Management Review, 2, 173-192. doi:10.1016/S1441-3523(99)70095-1

Slack, T., \& Hinings, B. (1992). Understanding change in national sport organizations: an integration of theoretical perspectives. Journal of Sport Management, 6, 114-132.

Slack, T., \& Hinings, B. (1994). Institutional pressures and isomorphic change: an Empirical Test. Organization Studies, 15, 804827.

Smith, A. C. T. (2004). Complexity theory and change management in sport organizations. E:CO Special Double Issue, 6, 7079.

Stenling, C., \& Fahlén, J. (2009). The order of logics in Swedish sport-feeding the hungry beast of result orientation and commercialization. European Journal for Sport and Society, 6 , 29-42.

Swiss Handball Association (2013, June 22). Jahresbericht 2012/13 [Annual Report 2012/13]. Retrieved from http:// www.handball.ch/de/shv/verband/protokolle.htm

Swiss Olympic (n.d.). Anzahl Mitglieder und Vereine der Verbände [Number of members and clubs of the federations]. Retrieved from http://swissolympic.ch/dam/jcr:86eb8e8430f2-4f2f-b2db-d7680a677def/Anzahl-Mitglieder-und-Vereine-Verbaende_2016_DE.pdf.pdf

Swiss Olympic (2013, October 1). Richtlinien für die Verbandsförderung [Federation Promotion Guideline]. Retrieved from http://www.swissolympic.ch/Portaldata/41/Resources/03_ sport/verbaende/spitzensport_konzept/Verbandsfoerderung_2013_10_01_DE.pdf

Swiss-Ski (n.d.a). Jahresbericht 2014/15 [Annual Report 2014/15]. Retrieved from https://www.swiss-ski.ch/ueber-swiss-ski/ verband/organisation/facts-figures/

Swiss Unihockey (n.d.d). Geschäftsbericht 2014/15 [Annual Report 2014/15]. Retrieved from http://www.swissunihockey. $\mathrm{ch} /$ de/administration/downloadcenter/

Swiss Volley (n.d.e). Jahresbericht 2015 [Annual Report 2015]. Retrieved from http://www.volleyball.ch/swiss-volley/verband/organe/volleyballparlament/

Todd, S. Y., Andrew, D. P. S., \& Sowieta, S. E. (2009). A personnel management case study in a Canadian national sport organisation. Sport Management Review, 12, 49-56. doi:10.1016/j. smr.2008.09.005

Vos, S., Breesch, D., Késenne, S., Van Hoecke, J., Vanreusel, B., \& Scheerder, J. (2011). Governmental subsidies and coercive pressures. Evidence from sport clubs and their resource dependencies. European Journal for Sport and Society, 8, 257280.

Washington, M., \& Patterson, K. D. W. (2011). Hostile takeover or joint venture: Connections between institutional theory and sport management research. Sport Management Review, 14, 1-12. doi:10.1016/j.smr.2010.06.003
Welty Peachey, J., Zhou, Y., Damon, Z. J., \& Burton, L. J. (2015). Forty years of leadership research in sport management: a review, synthesis, and conceptual framework. Journal of Sport Management, 29, 570-587. doi:10.1123/jsm.2014-0126

\section{Federation documents}

PluSport

PluSport (n.d.a). Jahresbericht 2004 [Annual Report 2004]. Retrieved from http://www.plusport .ch/plusport/jahresbericht/ archiv.html

PluSport (n.d.b). Geschäftsbericht 2009 [Annual Report 2009]. Retrieved from http://www.plusport.ch/plusport/jahresbericht/archiv.html

PluSport (n.d.c). Jahresbericht 2014 [Annual Report 2014]. Retrieved from http://www.plusport .ch/plusport/jahresbericht/ archiv.html

PluSport (n.d.d). Jahresbericht 2015 [Annual Report 2015]. Retrieved from http://www.plusport .ch/plusport/jahresbericht/archiv.html

PluSport (n.d.e) Jahresbericht 2016 [Annual Report 2016]. Retrieved from http://www.plusport .ch/plusport/jahresbericht/ archiv.html

PluSport (2012, January 21). Protokoll der 24. Präsidentinnen- und Präsidentenkonferenz [Protocol for the 24th Presidents> Conference]. Retrieved from www.plusport.ch/events/dv.html

PluSport (2012, May 30). Protokoll zur 54. Delegiertenversammlung [Protocol for the 54th Assembly of Delegates]. Retrieved from www.plusport.ch/events/dv.html

PluSport (2014, April). Budget 2014 und Finanzplanung 20152017 [Finance plan 2015-2017]. Retrieved from www.plusport.ch/events/dv.html

PluSport (2015, April). Jahresrechnung 2014 nach Swiss GAAP FER 21 [Annual Finance Report According to Swiss GAAP FER 21]. Retrieved from http://www.plusport .ch/plusport/jahresbericht/archiv.html

PluSport (2016, March). Strategie 2016-2019 [Strategy paper 2016-2019]. Unpublished document.

\section{Swiss Fencing}

Swiss Fencing (n.d.). Description de poste Secrétariat central [Job description General secretary]. Unpublished document.

Swiss Fencing (2011, Oct 12). SWOT Analyse [SWOT Analysis Swiss Fencing]. Unpublished document.

Swiss Fencing (2012, Oct 27). Concept de Promotion du Sport d Elite 2013-2016 [Promotion Concept for Elite Sport 20132016]. Unpublished document.

Swiss Fencing (2014, April 14). Création et gestion des comptes Twitter et Facebook par le management de Swiss Fencing [Creation and administration of Twitter and Facebook accounts through the management of Swiss Fencing]. Retrieved from http://www.swiss-fencing.ch/wp-content/ uploads/downloads/2014/04/FSE Reseau_sociaux.pdf 
Swiss Fencing (2015). Concept de promotion du Sport d’ Elite [Promotion Concept for Elite Sport]. Unpublished document.

Swiss Fencing (2015, Aug 6). Elite- und Nachwuchssportplanung - Saison 2015/2016 [Elite and Grassroots Sport Strategy - Season 2015/16]. Retrieved from http://www.swissfencing.ch/wp-content/uploads/downloads/2015/09/ Elitesportplanung_2015-16_d.pdf

Swiss Fencing (2015, September 25). Rapport de l'Assemblée Générale Sport Elite [General Assembly Report for Elite Sport 2015]. Unpublished document.

Wyrsch, P. (2016, April). Professionalisierung bei Swiss Fencing [Professionalization in Swiss Fencing] (unpublished master's thesis). Univeristy of Bern, Bern.

\section{Swiss Gymnastics}

Brühlmann, R. (2014, Nov). Professionalisierung im Schweizerischen Turnverband [Professionalization in Swiss Gymnastics Federation] (unpublished master's thesis). Univeristy of Bern, Bern.

Swiss Gymnastics Federation (n.d.a). Mehr als Turnen ["More than gymnastics" Federation Presentation]. Received personally, September 5, 2014.

Swiss Gymnastics Federation (n.d.b). Über uns [About us]. Retrieved September 14, 2017, from www.stv-fsg.ch/de/verband/ueber-uns/

Swiss Gymnastics Federation (n.d.c). Verbandsplanung 20142019 [Federation Strategy 2014-2019]. Retrieved from http:// www.stv-fsg.ch/de/verband/ueber-uns/downloads/

Swiss Gymnastics Federation (2008, September 16). Verbandsplanung 2009-2013 [Federation Planning 2009-2013]. Retrieved from http://www.stv-fsg.ch/de/verband/ueber-uns/ downloads/

Swiss Gymnastics Federation (2011, March 21). STV Marketingkonzept 2011-2013 [Marketing Concept]. Retrieved from http://www.stv-fsg.ch/de/verband/ueber-uns/downloads/

Swiss Gymnastics Federation (2014, April). Geschäftsbericht 2013 [Annual Report 2013]. Retrieved from http://www.stv-fsg. $\mathrm{ch} /$ de/verband/ueber-uns/downloads/

Swiss Gymnastics Federation (2015, A pril). Geschäftsbericht 2014 [Annual Report 2014]. Retrieved from http://www.stv-fsg. ch/de/verband/ueber-uns/downloads/

\section{Swiss Handball}

Swiss Handball Association (n.d.a). Historie - Handball in der Schweiz [History of Handball in Switzerland]. Retrieved from http://www.handball.ch/de/shv/verband/historie.htm

Swiss Handball Association (n.d.b). Visionen und Ziele [Visions and aims]. Retrieved from http://www.handball.ch/de/ shv/10_verband/visionen.htm

Swiss Handball Association (n.d.c). Ziele und Massnahmen [Goals and strategy]. Retrieved from http://www.handball.ch/de/ shv/10_verband/geschaeftsstelle.htm

Swiss Handball Association (2006, June 24). Jahresbericht 2005/06 zur 32. ordentlichen Delegiertenversammlung des Schweizerischen Handball-Verbandes [Annual Report 2005/06 for the 32th Assembly of Delegates]. Retreived from http://www. handball.ch/de/shv/10_verband/protokolle.htm

Swiss Handball Association (2011, June 25). Jahresbericht 2010/11 zur 37. ordentlichen Delegiertenversammlung des Schweizerischen Handball-Verbandes [Annual Report 2010/11 for the 37th Assembly of Delegates]. Retreived from http://www. handball.ch/de/shv/10_verband/protokolle.htm

Swiss Handball Association (2012, June 30). Jahresbericht 2011/12 zur 38. ordentlichen Delegiertenversammlung des Schweizerischen Handball-Verbandes [Annual Report 2011/12 for the 38th Assembly of Delegates]. Retreived from http://www. handball.ch/de/shv/10_verband/protokolle.htm

Swiss Handball Association (2013, June 22). Jahresbericht 2012/13 zur 39. ordentlichen Delegiertenversammlung des Schweizerischen Handball-Verbandes [Annual Report 2012/13 for the 39th Assembly of Delegates]. Retreived from http://www. handball.ch/de/shv/10_verband/protokolle.htm

Swiss Handball Association (2014, June 21). Jahresbericht 2013/14 zur ordentlichen Mitgliederversammlung des Schweizerischen Handball-Verbandes [Annual Report 2013/14 for the Assembly of Members]. Retreived from http://www. handball.ch/de/shv/10_verband/protokolle.htm

Swiss Handball Association (2015, June 20). Jahresbericht 2014/15 zur ordentlichen Mitgliederversammlung des Schweizerischen Handball-Verbandes [Annual Report 2014/15 for the Assembly of Members]. Retreived from http://www. handball.ch/de/shv/10_verband/protokolle.htm

Swiss Handball Association (2015, August 12). Kommunikationskonzept. Schweizerischer Handballverband [Communication Concept]. Retrieved from http://www.handball.ch/de/shv/ downloads.htm

Swiss Handball Association (2016, September 17). Jahresbericht 2015/16 zur ordentlichen Mitgliederversammlung des Schweizerischen Handball-Verbandes [Annual Report 2015/16 for the Assembly of Members]. Retreived from http://www. handball.ch/de/shv/verband/protokolle.htm

\section{Swiss Ski}

Geisser, R., \& Steffen, B. (2014, March 16). Wir brauchen mehr Mittel vom Staat [We need more resources from the State]. NZZ am Sonntag, retrieved from https://www.nzz.ch/nzzas/nzz-am-sonntag/wir-brauchen-mehr-mittel-vom-staat- 1.18263800

Swiss-Ski (n.d.a). Jahresbericht 2014/15 [Annual Report 2014/15]. Retrieved from https://www.swiss-ski.ch/ueber-swiss-ski/ verband/organisation/facts-figures/

Swiss-Ski (n.d.b). Kommunikationskonzept 2011-2014 [Communication concept 2011-2014] Received personally, September 28, 2015.

Swiss-Ski (n.d.c). Projekt- und Massnahmenplanung 2013-2016 [Project and Action Strategy Paper 2013-2016]. Received personally, September 28, 2015.

Swiss-Ski (n.d.d). Swiss-Ski Strategie 2013-2016 [Swiss-Ski Strategy Paper 2013-2016]. Received personally, September 28, 2015. 
Swiss-Ski (2011, April 1). Kommunikationsrichtlinien [Communication Guideline]. Received personally.

Swiss-Ski (2011, July 1). Geschäftsreglement der Geschäftsleitung [Directory Business Regulations]. Received personally.

Swiss-Ski (2011, July 1). Organisationsreglement des Präsidiums [Organization Regulations for Strategic Board]. Received personally.

Swiss-Ski (2015). Snowactive 1/2015. Retrieved from https:// www.swiss-ski.ch/ueber-swiss-ski/mitglieder/mitgliederbereich/snowactive/

Swiss-Ski (2015). Snowactive 2/2015. Retrieved from https:// www.swiss-ski.ch/ueber-swiss-ski/mitglieder/mitgliederbereich/snowactive/

\section{Swiss Unihockey}

Boesch, K. (2009, June 6). Gegenkandidaten für Thomas Gilardi portiert [Rival candidate of Thomas Gilardi ported]. Unihockey.ch, retrieved from http://unihockey.ch/meisterschaft/andere/gegenkandidaten-fr-thomas-gilardi-portiert-7127/

Das Ehrenamt im Verband Swiss Unihockey [Volunteering in Swiss Unihockey Federation] (2015, June). Unpublished volunteer survey. Univeristy of Bern, Bern.

Handlungsempfehlungen für das Relationship Marketing in swiss unihockey [Action recommendations to Swiss Unihockey for Relationship Marketing] (2013, April). Unpublished Club Presidents Survey. Univeristy of Bern, Bern.

Regionalisierung des Unihockeysports [Regionalization in floorball] (2013, February). Unpublished study. University of Bern, Bern.

Swiss Unihockey (n.d.a). Auswertung Kummerbox President's Day 2013 [Analysis Feedback Box of the President's Day 2013]. Received personally, May 8, 2015.

Swiss Unihockey (n.d.b). Geschäftsbericht 2012/13 [Annual Report 2012/2013]. Retrieved from http://www.swissunihockey.ch/de/administration/downloadcenter/

Swiss Unihockey (n.d.c). Geschäftsbericht 2013/14 [Annual Report 2013/2014]. Retrieved from http://www.swissunihockey.ch/de/administration/downloadcenter/

Swiss Unihockey (n.d.d). Geschäftsbericht 2014/15 [Annual Report 2014/15]. Retrieved from http://www.swissunihockey. ch/de/administration/downloadcenter/

Swiss Unihockey (n.d.e). Jahresbericht 2011/12 [Annual Report 2011/2012]. Retrieved from http://www.swissunihockey.ch/ de/administration/downloadcenter/

Swiss Unihockey (2014, October 27). Strategieunterlagen 20142018 [Strategy paper 2014-2018]. Received personally.

Swiss Unihockey (2015). Organisationshandbuch, Version 1 [Organization Handbook, 1 st version]. Unpublished document.

\section{Swiss Volley}

Professionalisierung der Regionalverbände von Swiss Volley [Professionalization of Regional Federation of Swiss Volley] (2016, June). Unpublished Regional Federation Survey. University of Bern, Bern.
Professionalisierung von Clubs. Fallstudie von Swiss Volley [Professionalization of Clubs. A case study Swiss Volley] (2016, June). Unpublished Club Survey. University of Bern, Bern.

Swiss Volley (n.d.a). Jahresbericht 2011 [Annual Report 2011]. Retrieved from http://www.volleyball.ch/swiss-volley/verband/organe/volleyballparlament/

Swiss Volley (n.d.b). Jahresbericht 2012 [Annual Report 2012]. Retrieved from http://www.volleyball.ch/swiss-volley/verband/organe/volleyballparlament/

Swiss Volley (n.d.c). Jahresbericht 2013 [Annual Report 2013]. Retrieved from http://www.volleyball.ch/swiss-volley/verband/organe/volleyballparlament/

Swiss Volley (n.d.d). Jahresbericht 2014 [Annual Report 2014]. Retrieved from http://www.volleyball.ch/swiss-volley/verband/organe/volleyballparlament/

Swiss Volley (n.d.e). Jahresbericht 2015 [Annual Report 2015]. Retrieved from http://www.volleyball.ch/swiss-volley/verband/organe/volleyballparlament/

Swiss Volley (2008, November). Swiss Volley Magazine, 2008/4. Retrieved from http://www.volleyball.ch/swiss-volley/services/downloads/archiv-swiss-volley-magazine/

Swiss Volley (2013, February). Swiss Volley Magazine, 2013/1. Retrieved from http://www.volleyball.ch/swiss-volley/services/downloads/archiv-swiss-volley-magazine/

Swiss Volley (2013, November). Swiss Volley Magazine, 2013/3. Retrieved from http://www.volleyball.ch/swiss-volley/services/downloads/archiv-swiss-volley-magazine/

Swiss Volley Media Communiqué (2015, February 5). SRG SSR zeigt Spitzenvolleyball live im Web [SRG SSR broadcasts toplevel volleyball live in web]. Retrieved from http://www.volleyball.ch/swiss-volley/medien/medienmitteilungen/2015/

Swiss Volley (2015, November 28). Volleyparlamentsordnung [Volley Parlament Reglement]. Retrieved from http://www. volleyball.ch/uploads/media/02.1_Volleyballparlamentsordnung_28.11.15.pdf

Swiss Volley Media communiqué (2016, March 1). Swiss Volley League Konferenz erhält Entscheidkompetenzen [More decision-making competences for Swiss Volley League Conference]. Retrieved from http://www.volleyball.ch/swiss-volley/medien/medienmitteilungen/2016/ 
Appendix: NSF-internal factors that facilitate or hinder NSFs in meeting expectations from their environment for professionalization.

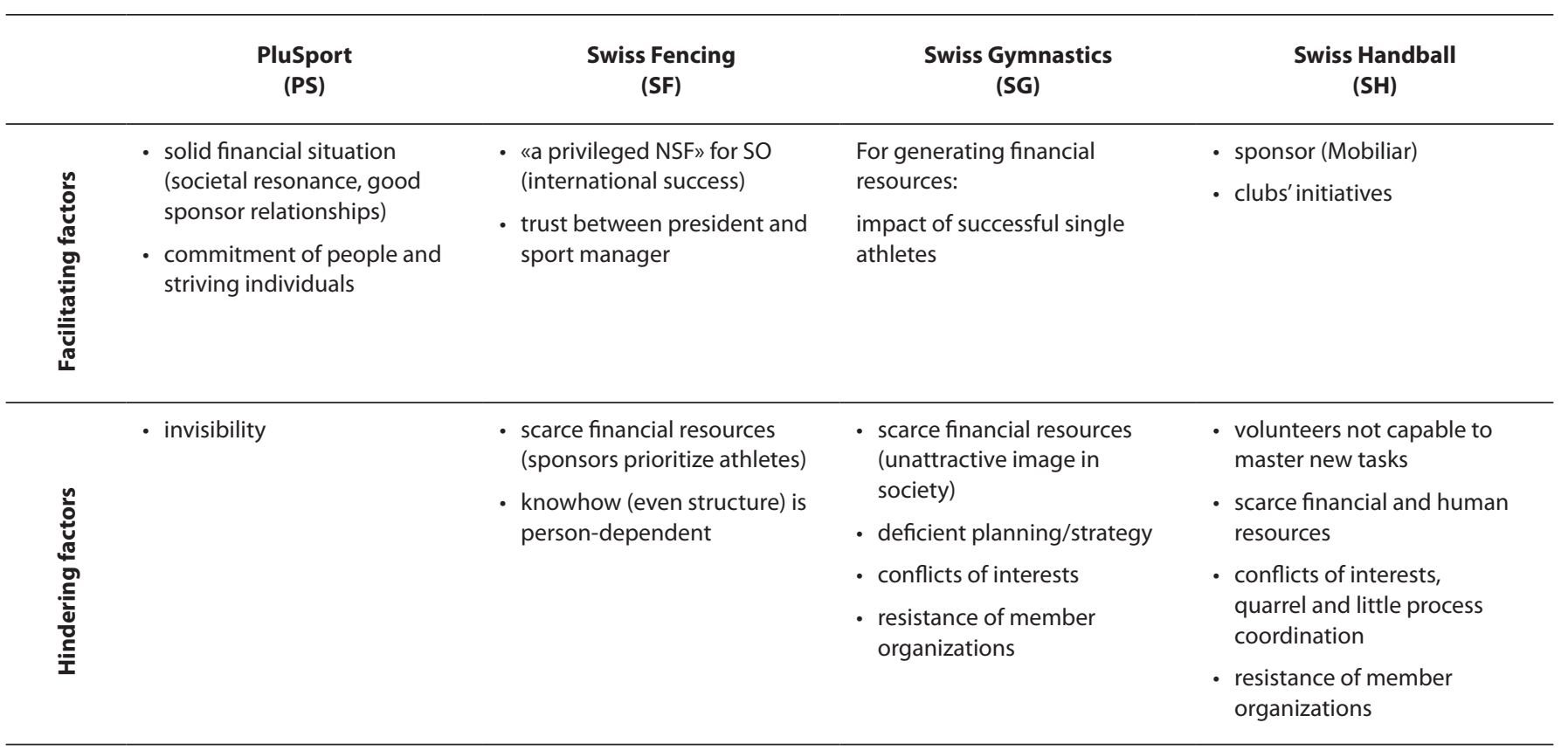

\begin{tabular}{|c|c|c|c|}
\hline & $\begin{array}{l}\text { Swiss Ski } \\
\text { (SS) }\end{array}$ & $\begin{array}{l}\text { Swiss Unihockey } \\
\text { (SU) }\end{array}$ & $\begin{array}{l}\text { Swiss Volley } \\
\text { (SV) }\end{array}$ \\
\hline 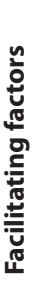 & $\begin{array}{l}\text { - solid financial situation } \\
\text { (good sponsor relationships, } \\
\text { international success) } \\
\text { - popularity, media presence }\end{array}$ & $\begin{array}{l}\cdot \text { - solid financial situation } \\
\text { - } \text { sponsor (Mobiliar) } \\
\text { - clubs'initiatives } \\
\text { - striving individuals }\end{array}$ & $\begin{array}{l}\text { - } \text { sponsor (Mobiliar) } \\
\text { - trust between president(s) } \\
\text { and GD } \\
\text { - active committees } \\
\text { - (clubs generally willing for } \\
\text { development) } \\
\text { - GD }\end{array}$ \\
\hline 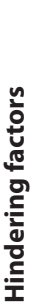 & $\begin{array}{l}\text { - discrepancy between } \\
\text { organization of sport and } \\
\text { administration } \\
\text { - structure } \\
\text { - conflicts of interests } \\
\text { - lacking knowhow (staff and } \\
\text { discontinuity) }\end{array}$ & $\begin{array}{l}\text { - little (media) presence } \\
\text { - scarce financial and human } \\
\text { resources } \\
\text { - vision incoherence and } \\
\text { communication NSF-clubs } \\
\text { - conflicts of interests } \\
\text { inadequate infrastructure }\end{array}$ & $\begin{array}{l}\text { - little (media) presence and } \\
\text { acknowledgment in society } \\
\text { - scarce financial and human } \\
\text { resources } \\
\text { - resistance of member } \\
\text { organizations } \\
\text { - inadequate infrastructure }\end{array}$ \\
\hline
\end{tabular}

